\title{
Purification of Piscirickettsia salmonis and partial characterization of antigens
}

\author{
M. N. Barnes ${ }^{1, *}$, M. L. Landolt ${ }^{1}$, D. B. Powell ${ }^{2}$, J. R. Winton ${ }^{3, * *}$ \\ ${ }^{1}$ School of Fisheries, University of Washington, PO Box 357980, Seattle, Washington 98195, USA \\ ${ }^{2}$ Alpharma Inc., 1720 130th Avenue N.E., Bellevue, Washington 98005 , USA \\ ${ }^{3}$ Western Fisheries Research Center, 6505 N.E. 65 th St., Seattle, Washington 98115 , USA
}

\begin{abstract}
Piscirickettsia salmonis is the etiological agent of salmonid rickettsial septicemia, an economically significant disease affecting the salmon aquaculture industry. As with other rickettsial pathogens, antigenic analysis of $P$. salmonis has been limited by the inherent difficulties of purifying an intracellular organism away from host cell material. In this report, we describe the use of diatrizoate meglumine and diatrizoate sodium (DMDS) density gradient centrifugation to purify $P$. salmonis grown in chinook salmon embryo (CHSE-214) cells. Plaque assay titers and total protein assays confirmed that viable $P$. salmonis was consistently concentrated in a visible band within the DMDS density gradient at a density of 1.15 to $1.16 \mathrm{~g} \mathrm{~m}^{-1}$. Recovery of purified, viable organisms from DMDS density gradients varied from 0.6 to $3 \%$. Preparations of uninfected CHSE- 214 cells, CHSE-214 cells infected with $P$. salmonis, and gradient-purified $P$. salmonis were compared using sodium dodecyl sulfate polyacrylamide gel electrophoresis to assess the degree of purification and to identify $P$. salmonis-specific proteins. Although gradient-purified $P$. salmonis preparations were not completely free of host cell material, 8 bacterial proteins were identified. Polyclonal rabbit antiserum was used in an immunoblot of proteins from purified $P$. salmonis to identify 3 major and 5 minor antigens. The major antigens of 56, 30 and $20 \mathrm{kDa}$ were potential candidates for experimental vaccines and development of novel diagnostic assays.
\end{abstract}

KEY WORDS: Piscirickettsia salmonis · Rickettsia $\cdot$ Fish disease $\cdot$ Salmonid · Antigen

\section{INTRODUCTION}

Various 'rickettsia-like' Gram-negative bacteria have been associated with fish, molluscs and crustaceans (Fryer \& Lannan 1994). While many of these agents in fish have only been described by light or electron microscopy (Almendras \& Fuentealba 1997, Fryer \& Mauel 1997), Piscirickettsia salmonis, the etiological agent of salmonid rickettsial septicemia or piscirickettsiosis, has been isolated and characterized in terms of its in vitro culture requirements and the lesions it induces (Fryer et al. 1990, Branson \& Diaz-Munoz 1991, Cvitanich et al. 1991, Olsen et al. 1997). Sequence analysis of the 16S rRNA gene led to taxonomic place-

\footnotetext{
- Present address: Alaska District Veterinary Command, 1060 Gaffney Road, Ft. Wainwright, Alaska 99703, USA

*Addressee for correspondence.

E-mail: jim_winton@usgs.gov
}

ment of $P$. salmonis within the family Rickettsiaceae (Fryer et al. 1992). Infectivity studies by Cvitanich et al. (1991), Garcés et al. (1991) and Smith et al. (1996) fulfilled Koch's postulates and demonstrated a doseresponse with mortality reaching nearly $100 \%$ in some groups of coho (Oncorhynchus kisutch) and Atlantic salmon (Salmo salar) injected with the bacterium. Disease diagnosis is possible by light microscopy, immunofluorescent staining (Lannan \& Fryer 1991, Lannan et al. 1991, Olsen et al. 1997), latex bead agglutination (Kuzyk et al. 1996), and polymerase chain reaction (Mauel et al. 1996). Two carbohydrate and 4 protein moieties, tentatively identified as surface-exposed antigens, were identified by Kuzyk et al. (1996) using sera from rabbits immunized with $P$. salmonis.

Following the original description of Piscirickettsia salmonis from Chile, reports appeared of rickettsial organisms in salmonids from other countries (Brocklebank et al. 1993, Rodger \& Drinan 1993, Olsen et al. 
1997) which described clinical and postmortem findings similar to those of piscirickettsiosis, but often with lower mortality rates than those observed in Chile. Differences among these outbreaks may represent $P$. salmonis infections in less susceptible fish, lessstressful rearing conditions, or different strains of the organism. While isolates of rickettsia from salmon in Canada, Norway and Ireland appear to be serologically (Lannan \& Fryer 1993, Alday-Sanz et al. 1994) and genetically (Mauel et al. 1996) related to the original Chilean isolate of $P$. salmonis (LF-89), at least 1 other Chilean isolate (EM-90) appears to be slightly different at the DNA sequence level (Mauel et al. 1996, Fryer \& Mauel 1997).

An important stage in the characterization of rickettsial proteins is the purification of the organism away from components of the cell culture in which it is grown. Intracellular bacteria are often incompletely released from cells, and more than half of the total infectious yield may remain associated with intact cells or cell debris (Moulder 1985). This appears to be the case with Piscirickettsia salmonis, which was shown in scanning electron micrographs to adhere to host-cell material (Fryer et al. 1990). Several techniques have been used to purify various rickettsia (Tamura et al. 1982). Isopycnic density gradient centrifugation in Percoll or in $66 \%$ diatrizoate meglumine and $10 \%$ diatrizoate sodium (DMDS; commercially known as Renografin or Hypaque) is commonly used and allows recovery of viable organisms. Recovery of metabolically active rickettsia after DMDS density gradient centrifugation can be relatively good, reaching as high as $40 \%$ from yolk-sac culture with minimal host cell contamination (Weiss et al. 1975). A Percoll density gradient centrifugation technique, modified from Tamura et al. (1982), was used by Kuzyk et al. (1996) to purify $P$. salmonis from cultured cells, but these workers did not report yield or determine viability of the purified organisms.

In this study, Piscirickettsia salmonis was purified from cell culture by DMDS density gradient centrifugation and the buoyant density and viability of $P$. salmonis were determined for fractions collected from the gradient. Material from the gradient fractions was separated by sodium dodecyl sulfate polyacrylamide gel electrophoresis (SDS-PAGE) and then stained to determine whether $P$. salmonis had been purified sufficiently from the host-cell culture to identify bacterial proteins. Immunoblotting (Towbin et al. 1979) with polyclonal rabbit antiserum made against $P$. salmonis (Lannan et al. 1991) was used to identify $P$. salmonis antigens. The results from this study have furthered our knowledge of the protein antigens of $P$. salmonis and identified several proteins potentially useful in diagnostic assays or for production of experimental vaccines.

\section{MATERIALS AND METHODS}

Growth and assay of Piscirickettsia salmonis. The American Type Culture Collection (ATCC) type strain (LF-89) of $P$. salmonis (ATCC VR-1361) was continuously propagated in a chinook salmon embryo cell line (CHSE-214; ATCC CRL 1681; Lannan et al. 1984) using antibiotic-free medium as described by Fryer et al. (1990). Monolayers of CHSE-214 cells were grown at $15^{\circ} \mathrm{C}$ in sealed flasks containing minimum essential medium (MEM), supplemented with $0.3 \%(\mathrm{w} / \mathrm{V})$ tryptose phosphate, $2 \mathrm{mM}$ L-glutamine, and $10 \%$ (v/v) fetal bovine serum and buffered to $\mathrm{pH} 7.9$ with sodium bicarbonate (MEM-10). Every 7 to $10 \mathrm{~d}$, the MEM-10 in a CHSE-214 culture flask was replaced with MEM without fetal bovine serum (MEM-0) and the flask inoculated with fluid from a $P$. salmonis-infected culture. Cells infected with $P$. salmonis were incubated at $15^{\circ} \mathrm{C}$ for 10 to $20 \mathrm{~d}$ before use.

Titers of $P$. salmonis were determined using a modified plaque assay. Serial dilutions of $P$. salmonis were plated on monolayers of CHSE-214 cells in 24-well plates and incubated for $1 \mathrm{~h}$ at $15^{\circ} \mathrm{C}$. During the absorption period, the plates were centrifuged at $200 \times$ $g$ for $15 \mathrm{~min}$ at $4^{\circ} \mathrm{C}$ to facilitate attachment of $P$. salmonis to the cells prior to addition of an overlay composed of $0.7 \%$ methycellulose in MEM-5. Plates were incubated for $17 \mathrm{~d}$ then fixed and stained for $1 \mathrm{~h}$ using a solution of $0.5 \%$ crystal violet in $18 \%$ formaldehyde.

Density gradient centrifugation. Linear DMDS density gradients were prepared using a conical-bore gradient maker connected to a peristaltic pump (Auto Densi-flow II $C_{\text {; }}$ Buchler Instruments, Lexena, KS, USA). Solutions of 30 and $67 \%$ (v/v) DMDS (Hypaque-76; Nycomed Amersham, Preston, NJ, USA) were prepared in distilled water, and $17 \mathrm{ml}$ of each solution was mixed to create the gradients in $25 \times$ $89 \mathrm{~mm}$ clear ultracentrifuge tubes. Sample suspensions were layered on top of the gradients and centrifuged at $52000 \times g$ for $90 \mathrm{~min}$ at $4^{\circ} \mathrm{C}$ in a SW 28 swinging bucket rotor (Beckman Instruments, Fullerton, CA, USA).

After centrifugation, each gradient was aspirated in $2 \mathrm{ml}$ fractions into $11 \times 34 \mathrm{~mm}$ ultracentrifuge tubes using a peristaltic pump and an automated fraction collector. Refractometer readings were taken of each fraction and standard curves of DMDS were used to convert refractive index to density in $\mathrm{g} \mathrm{m}^{-1}$. A small aliquot was collected from each fraction of gradients containing infected samples for determination of Piscirickettsia salmonis titer by a modified plaque assay. If total protein was measured, the fractions were centrifuged at $35000 \times g$ for $20 \mathrm{~min}$ at $4^{\circ} \mathrm{C}$ in a TLS-55 swinging bucket rotor (Beckman Instruments) to remove the DMDS. The pellets were resuspended in 
$0.5 \mathrm{ml}$ of distilled water and protein measurements were made using the Bradford protein assay (Bradford 1976).

Buoyant density and viability of gradient-purified Piscirickettsia salmonis. Sterile $4 \mathrm{~mm}$ glass beads were added to two $25 \mathrm{~cm}^{2}$ flasks of CHSE-214 cells infected with $P$. salmonis. After 10 min agitation, the contents of the flasks were transferred to a $50 \mathrm{ml}$ conical-bottom centrifuge tube and a sample taken to determine the initial $P$. salmonis titer by a modified plaque assay. The remaining material was sonicated with a $3 \mathrm{~mm}$ exponential microprobe (MSE Soniprep 150; Curtin Matheson Scientific, Houston, TX, USA) for $6 \mathrm{~s}$ at $22 \mu \mathrm{m}$ amplitude, then centrifuged at $200 \times \mathrm{g}$ for $12 \mathrm{~min}$ at $4^{\circ} \mathrm{C}$ to remove large cellular debris. The supernatant was decanted and retained. In an effort to extract more organisms from the pellet, $10 \mathrm{ml}$ of MEM-O was added to the original pellet, which was resonicated, centrifuged as before and the supernatant decanted and added to the first extraction. The combined supernatants were centrifuged at $35000 \times g$ for $20 \mathrm{~min}$ at $4^{\circ} \mathrm{C}$ in a SW 28 swinging bucket rotor. The sample pellet was resuspended in $0.5 \mathrm{ml}$ of MEM-0 then layered on a $34 \mathrm{ml}, 30-67 \%$ linear DMDS density gradient which was centrifuged and fractionated and the $P$. salmonis titer of each fraction determined as described. In an effort to provide additional purification, infected material was prepared as above except that, prior to density gradient centrifugation, the pellet was suspended in $20 \mathrm{ml}$ of MEM-0 and centrifuged through a $10 \mathrm{ml}, 35 \%$ DMDS cushion at $35000 \times g$ for 40 min at $4^{\circ} \mathrm{C}$

Comparison of total protein in gradient fractions. Four treatment groups were compared, consisting of Piscirickettsia salmonis-infected CHSE-214 cells, uninfected CHSE-214 cells, uninfected CHSE-214 cells given 2 freeze-thaw cycles followed by 10 strokes in a Dounce homogenizer, and uninfected CHSE-214 cells sonicated for $5 \mathrm{~min}$ at $20 \mu \mathrm{m}$ amplitude. To prepare the samples, eight $150 \mathrm{~cm}^{2}$ flasks of CHSE-214 cells were rinsed twice with MEM-0 to decrease any remaining serum proteins and $25 \mathrm{ml}$ of MEM-0 was dispensed into each flask. Two flasks were inoculated with $0.6 \mathrm{ml}$ of supernatant from a $P$. salmonis-infected CHSE-214cell culture. The flasks were incubated for $8 \mathrm{~d}$ at $15^{\circ} \mathrm{C}$, after which cells and supernatant from the 2 infected flasks and from 2 of the 6 uninfected control flasks were removed using a cell scraper and put into $50 \mathrm{ml}$ centrifuge tubes. Two additional flasks of uninfected cells were set into $\mathrm{a}-70^{\circ} \mathrm{C}$ freezer for $15 \mathrm{~min}$, thawed in a warm $\left(38^{\circ} \mathrm{C}\right)$ water bath, refrozen and thawed again. The cells were scraped from the flasks and transferred into a Dounce homogenizer, given 10 strokes, then transferred to a $50 \mathrm{ml}$ centrifuge tube. The contents of the fourth pair of flasks were scraped into a tube set in an ice bath, and the cells sonicated as described above. The cell slurry from each of the 4 treatments was prepared for density gradient centrifugation as described previously except that a 21 gauge needle was used to suspend the cells before differential centrifugation.

Sample preparation for SDS-PAGE. Three preparations were compared by SDS-PAGE: uninfected CHSE-214 cells, CHSE-214 cells infected with Piscirickettsia salmonis, and $P$. salmonis purified by density gradient centrifugation. To prepare the first 2 samples, four $150 \mathrm{~cm}^{2}$ flasks of CHSE-214 cells were rinsed twice with MEM-0 and $25 \mathrm{ml}$ of MEM-0 was dispensed into each flask. Two flasks were inoculated with $0.6 \mathrm{ml}$ of supernatant from a $P$. salmonis-infected CHSE-214cell culture. After $13 \mathrm{~d}$ of incubation at $15^{\circ} \mathrm{C}$, the cells and supernatant were scraped from each pair of flasks and centrifuged at $35000 \times g$ for $20 \mathrm{~min}$ at $4^{\circ} \mathrm{C}$ in a SW 28 rotor. The supernatant was discarded and the pellets were suspended in distilled water to a concentration of $50 \mu \mathrm{l} \mathrm{ml}^{-1}$ total protein, as determined by Bradford protein assay (Bradford 1976).

The purified Piscirickettsia salmonis sample was obtained from fractions of a DMDS density gradient. The $P$. salmonis titer of the $4 \mathrm{ml}$ volume of gradient material, measured by plaque assay, was $9.6 \times 10^{7} \mathrm{PFU}$ $\mathrm{ml}^{-1}$. The gradient fraction, containing purified $P$. salmonis in DMDS, was centrifuged at $35000 \times g$ for $20 \mathrm{~min}$ at $4^{\circ} \mathrm{C}$ in a TLS-55 rotor and resuspended in $0.5 \mathrm{ml}$ distilled water to a concentration of $50 \mu \mathrm{l} \mathrm{ml} \mathrm{m}^{-1}$ total protein.

SDS-PAGE. Samples were mixed with SDS sample buffer, containing $25 \%(\mathrm{v} / \mathrm{v}) 0.5 \mathrm{M}$ Tris- $\mathrm{HCl}, 20 \%(\mathrm{v} / \mathrm{v})$ glycerol, $4 \%(\mathrm{w} / \mathrm{v}) \mathrm{SDS}, 2 \%(\mathrm{v} / \mathrm{v})$ 2-mercaptoethanol, and $0.001 \%(\mathrm{w} / \mathrm{v})$ bromphenol blue. The mixture was heated to $100^{\circ} \mathrm{C}$ and held there for $5 \mathrm{~min}$, then each sample, containing $1.5 \mu \mathrm{g}$ total protein in $40 \mu \mathrm{l}$, was loaded into a well of a $10 \%$ SDS-PAGE gel, prepared as described by Ausubel et al. (1994) after the method of Laemmli (1970). Pre-stained standard proteins (BioRad, Hercules, CA, USA) were added to wells on either side of the experimental samples. The electrophoretic apparatus (Mini-protean II electrophoresis system; Bio-Rad) had $100 \mathrm{~V}$ applied across it for approximately $45 \mathrm{~min}$ at room temperature until the dye front reached the bottom of the gel.

The SDS-PAGE gels were fixed in $45 \%$ methanol and $10 \%$ acetic acid for $2 \mathrm{~h}$, then stained with $0.05 \%$ Coomassie brilliant blue R-250 in 50\% methanol and $10 \%$ acetic acid for $1 \mathrm{~h}$. The gels were destained in fixing solution until the background was nearly transparent and the bands clearly visible.

Immunoblotting. Anti-Piscirickettsia salmonis rabbit serum for the primary antibody was the kind gift of C. Lannan, Oregon State University, Corvallis, $O R$, 
USA and was prepared as described by Lannan et al. (1991). To prepare the immunoblots, SDS-PAGE gels were loaded with $0.5 \mu \mathrm{g}$ total protein in each lane and the gels run as described. The separated proteins in the unstained gels were electrophoretically transferred to a polyvinylidene difluoride (PVDF) membrane (Immobilon P; Millipore, Bedford, MA, USA) using $100 \mathrm{~V}$ for $1 \mathrm{~h}$ at $4^{\circ} \mathrm{C}$. The membranes were shaken in $5 \%(\mathrm{w} / \mathrm{V})$ non-fat dry milk in $10 \mathrm{mM}$ Tris- $\mathrm{HCl}(\mathrm{pH}$ 8) with $150 \mathrm{mM} \mathrm{NaCl}$ (TBS) for $1 \mathrm{~h}$ at room temperature. The membranes were rinsed in TBS with $0.05 \%$ Tween 20 (TBST), immersed in the primary antibody diluted 1:200 in TBST and shaken for $90 \mathrm{~min}$. The secondary antibody was a peroxidase labeled anti-rabbit goat serum (Bio-Rad). It was diluted to 1:2000 in TBST. The membranes were rinsed twice in TBST for $20 \mathrm{~min}$ before immersion in the secondary antibody with further shaking for $90 \mathrm{~min}$. Finally, the membranes were rinsed 3 times for 20 min with TBST and developed with a colour-developing reagent (Horseradish Peroxidase Conjugate Substrate Kit; BioRad).

\section{RESULTS}

\section{Density gradient centrifugation}

After centrifugation, the DMDS density gradients containing material from cultures infected with Piscirickettsia salmonis had hazy white bands that were significantly larger and at a different position to the thin bands observed in gradients with material from uninfected CHSE-214 cells. Typical gradients containing material from $P$. salmonis-infected cells had a single band located at a density of 1.15 to $1.16 \mathrm{~g} \mathrm{ml}^{-1}$. In gradients containing preparations of $P$. salmonisinfected cultures that had been given prior centrifugation through a DMDS cushion, 2 indistinct bands were observed between 1.13 and $1.18 \mathrm{~g} \mathrm{ml}^{-1}$.

\section{Buoyant density and viability of gradient-purified Piscirickettsia salmonis}

Refractive index measurements of comparable fractions from different gradients within a given centrifuge run showed that uniform, linear and reproducible gradients were created by the procedure used in our experiments (data not shown). Viable $P$. salmonis was consistently found in those fractions of DMDS gradients having a density of 1.15 to $1.16 \mathrm{~g} \mathrm{mI}^{-1}$ (Fig. 1). Based on starting titers of the resuspended pellets that

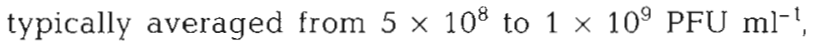
recovery of viable $P$. salmonis from the gradient fractions containing a visible band ranged from 0.6 to $3 \%$.

\section{Total protein comparison}

The total protein in gradients containing material from uninfected cells, regardless of how prepared, was located almost exclusively in the top 1 to 2 fractions of the gradient having an average density of 1.11 to $1.12 \mathrm{~g} \mathrm{ml}^{-1}$ (Fig 2). Gradients containing material from infected cells also had a large amount of protein in these upper fractions, but showed a second peak of total protein in those fractions having a density of 1.14 to $1.17 \mathrm{~g} \mathrm{ml}^{-1}$ (Fig. 2) that was associated with a peak in titer of $P$. salmonis.

\section{SDS-PAGE}

Following SDS-PAGE, different banding patterns were observed in lanes loaded with preparations of 
Fig. 2. Protein concentration in fractions of density gradients containing material from infected and uninfected CHSE-214 cells. Four preparations were compared: CHSE-214 cells infected with Piscirickettsia salmonis, and uninfected cells left untreated, sonicated, or given 2 freeze-thaw cycles. After aspiration through a $21 \mathrm{G}$ needle, each sample was clarified, pelleted and layered on top of a DMDS density gradient and centrifuged at $52000 \times g$ for $90 \mathrm{~min}$. The average density of gradient fractions 1 to 2 was 1.11 to $1.12 \mathrm{~g} \mathrm{ml}^{-1}$
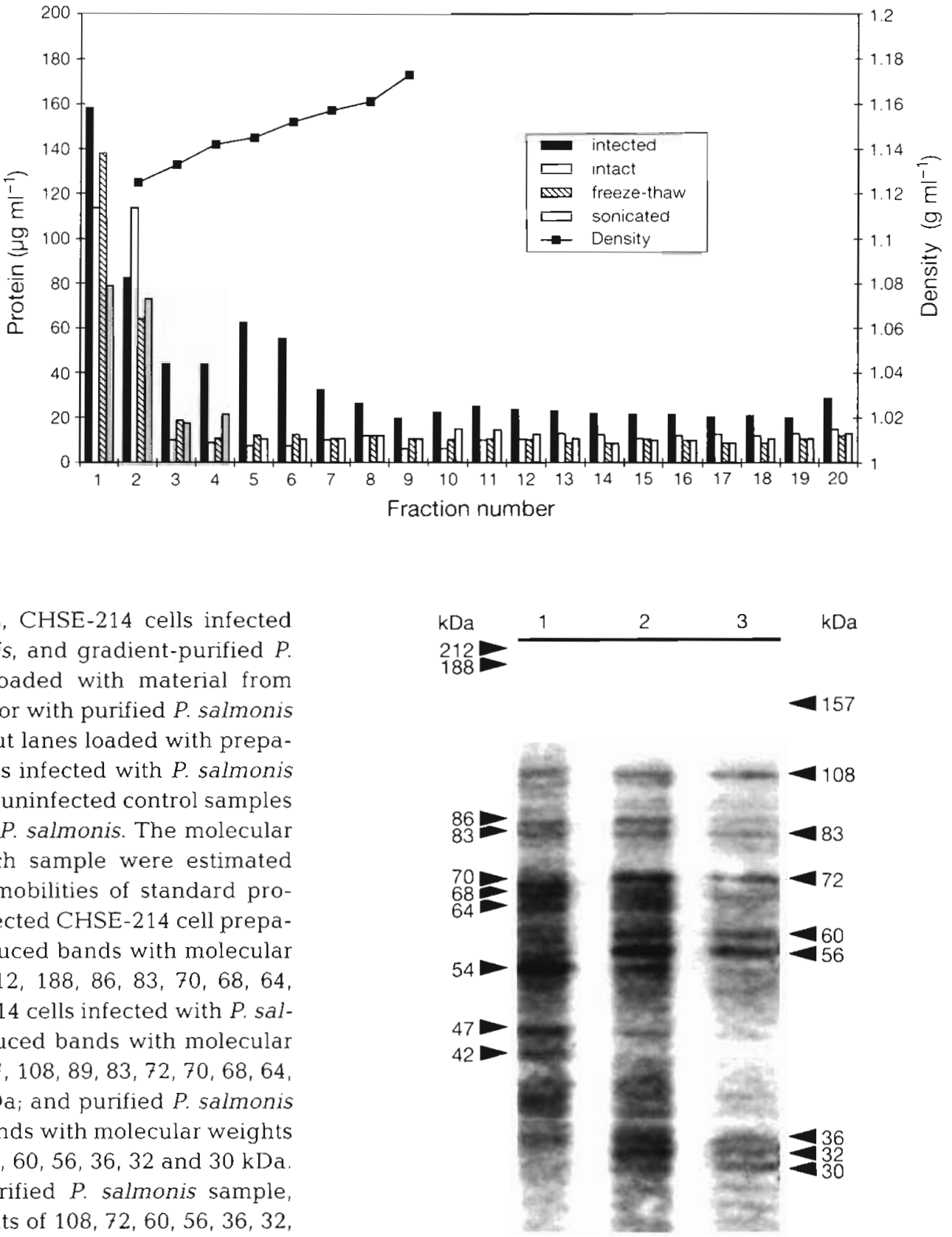

Fig. 3. Preparations of uninfected CHSE-214 cells (lane 1), CHSE-214 cells infected with Piscirickettsia salmonis (lane 2), and gradient-purified $P$. salmonis (lane 3 ) compared using sodium dodecyl sulfate polyacrylamide gel electrophoresis (SDS-PAGE). For the first 2 samples, flasks of CHSE-214 monolayers were either inoculated with $P$. salmonis or left uninfected. The purified $P$. salmonis sample was obtained from fractions 5 and 6 of the density gradient containing infectious material used in the protein comparison study (Fig. 2). All preparations were centrifuged and resuspended in distilled water to a concentration of $50 \mu \mathrm{l} \mathrm{ml}^{-1}$ total protein. Samples mixed with SDS sample buffer were heated to $100^{\circ} \mathrm{C}$ for $5 \mathrm{~min}$; then each sample, containing $1.5 \mu \mathrm{g}$ total protein in $40 \mu \mathrm{l}$, was loaded into a sample well of a $10 \%$ SDS-PAGE gel. The gel was stained with Coomassie brilliant blue 


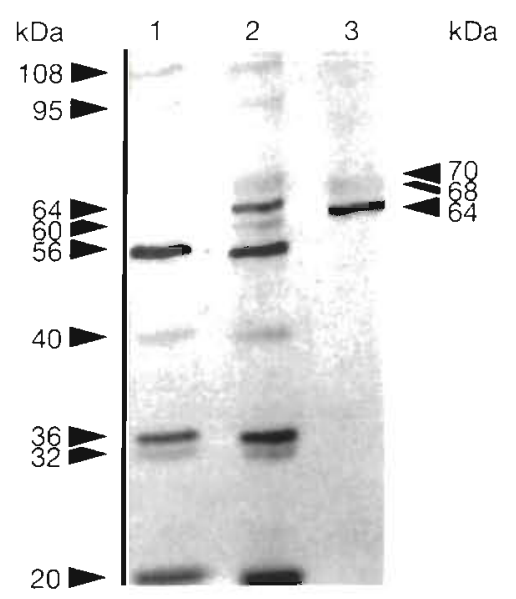

Fig. 4. Comparison of a preparation of purified Piscirickettsia salmonis (lane 1), CHSE-214 cells infected with $P$. salmonis (lane 2), and uninfected CHSE-214 cells (lane 3) in an immunoblot. Unstained SDS-PAGE gels with $0.5 \mu \mathrm{g}$ total protein in $15 \mu \mathrm{l}$ of buffered sample in each lane were prepared and the separated proteins were electrophoretically transferred to a polyvinylidene difluoride membrane. Antigens were visualized using anti- $P$. salmonis polyclonal rabbit serum and antirabbit goat serum as primary and secondary antibodies, respectively, then developed with a commercial horseradish peroxidase conjugate substrate kit

ties of pre-stained protein standards run in each gel. Purified $P$. salmonis (Fig. 4, lane 1) had antigens of $108,95,64,60,56,40,36,32$, and $20 \mathrm{kDa}$; CHSE-214 cells infected with $P$. salmonis (Fig. 4, lane 2) had antigens of $108,95,70,68,64,60,56,40,36,32$, and 20 $\mathrm{kDa}$; while uninfected CHSE-214 cells (Fig. 4, lane 3) had antigens of 70,68 , and $64 \mathrm{kDa}$ that reacted with this rabbit antiserum. The major antigens of $P$. salmonis were proteins of 56,36 and $20 \mathrm{kDa}$. A $64 \mathrm{kDa}$ protein in uninfected CHSE-214 cells was strongly recognized by this particular antiserum.

\section{DISCUSSION}

The effectiveness of DMDS density gradient centrifugation for the concentration and purification of Piscirickettsia salmonis was demonstrated by consistently finding viable organisms and higher protein levels in fractions of the gradients having a density of 1.15 to $1.16 \mathrm{~g} \mathrm{ml}^{-1}$. The yield of purified $P$. salmonis in this study, while low, was generally consistent with other reported rickettsial purifications from cell culture systems (Weiss et al. 1975). Proteins from uninfected CHSE-214 cell cultures, even if manipulated to mimic cell lysis due to infection, were not found at the same density. Between preparations of uninfected CHSE214 cells and of purified P. salmonis, the SDS-PAGE protein profiles and the antigens identified by im- munoblotting were nearly mutually exclusive. In western blots, the loss of a $64 \mathrm{kDa}$ protein that was strongly reactive in the uninfected CHSE-214 sample lane, but nearly absent in the purified $P$. salmonis sample lane, was indicative of the efficiency of separation between target organism and host cell culture

In an effort to increase purity, a few of the gradients were loaded with preparations of Piscirickettsia salmonis that had been pelleted through a cushion of DMDS prior to density gradient centrifugation. The cause of the double band observed in these gradients was not clear. While we did not compare the 2 bands by SDS-PAGE or western blotting assays, protein levels in the higher density band were greater and titers of infectious material were less, suggesting the lower band contained damaged cells. Kuzyk et al. (1996) found a double band after Percoll density centrifugation of $P$, salmonis, and determined that the low-density band was devoid of whole cells. Wiebe et al. (1972) found Coxiella burnetii produced 2 bands in a density gradient. Both bands contained viable cells, but the lighter organisms were smaller and had condensed nucleoid material. Hanson et al. (1981) reported that Rickettsia prowazekii had greater viability in the lighter of 2 bands formed in a density gradient. This coincided with functional cytoplasmic membranes in the more buoyant organisms, which responded to the high osmolarity of the DMDS by visibly retracting their protoplasm from the membrane outer envelope.

Sonicated and freeze-thaw control treatments were included in the total protein comparison to mimic, as much as possible, the disruption of CHSE-214 cells by infection with Piscirickettsia salmonis. The mechanical disruption was an attempt to determine whether any of the normal CHSE-214 cell proteins had the same buoyant density as $P$. salmonis and thus might contaminate the purified sample. As demonstrated by their location at a density of 1.11 to $1.12 \mathrm{~g} \mathrm{ml}^{-1}$ in control gradicnts, CHSE-214 proteins were much lighter than $P$. salmonis cells. Consequently, a wider band with diffuse margins and having a lower density would be expected if many CHSE-214 proteins remained in preparations of purified $P$. salmonis.

As expected, staining intensity in the immunoblot did not mirror the amount of protein observed in the SDS-PAGE gel. For example, the 56, 36 and $20 \mathrm{kDa}$ proteins of the purified Piscirickettsia salmonis preparation were strongly reactive with the polyclonal rabbit serum and appeared to be the 3 immunodominant antigens (at least for rabbits). Because the polyclonal rabbit antiserum used in this study had been prepared against $P$. salmonis grown in CHSE-214 cell cultures without extensive purification (Lannan et al. 1991), it was not surprising that several antigens of 
uninfected CHSE-214 cells were reactive in our immunoblots. Conclusions about the immunogenicity of any of the proteins, especially for fish, will require further studies using sera from several individuals of the principal host species which have survived natural infections.

In a study similar to the one reported here, Kuzyk et al. (1996) used Percoll gradients to purify the LF-89 strain of Piscirickettsia salmonis from cultures of infected CHSE-214 cells. While they did not provide estimates of buoyant density or viability, transmission electron microscopy was used to show that a major, diffuse, high-density band contained material that appeared to be purified $P$. salmonis. The high-density band was used to generate a specific polyclonal rabbit antiserum for immunofluorescence and immunogold staining and for western blot analysis of antigenic proteins. Six immunoreactive antigens were observed at relative sizes of $65,60,54,51,16$, and $11 \mathrm{kDa}$. The 16 and $11 \mathrm{kDa}$ antigens resisted digestion with proteinase $\mathrm{K}$ and were judged to be carbohydrate antigens. The other 4 antigens were thought to be proteins, 3 of which $(65,60$, and $54 \mathrm{kDa})$ had estimated molecular weights similar to 3 of the 9 antigens identified in our study. The antigens in the 56 to $60 \mathrm{kDa}$ range identified by both studies are close in size to the $58 \mathrm{kDa}$ protein of Rickettsia tsutsugamushi, which is homologous to the highly conserved family of Hsp60 heat shock proteins (Hoiby 1975, Stover et al. 1990a, b).

The most likely explanations for differences in the number and molecular weights of the antigens identified by Kuzyk et al. (1996) and those reported here are the use of a different density gradient medium (Percoll vs DMDS) for separation of $P$. salmonis and the use of a different rabbit for antiserum production. The immune system of an individual mammal or fish may recognize different epitopes or different proteins entirely, and thus may not provide consistent patterns in immunoblots. Although teleosts are primitive vertebrates, they are able to produce IgM-like (Ig: immunoglobin) antibodies of comparable specificity and affinity to their mammalian counterparts (Richter \& Ambrosius 1979, 1988, Richter et al. 1989, Mochida et al. 1994). However, fish may be less able than mammals to respond to multiple antigens (Mochida et al. 1994). In fact, when Kuzyk et al. (1996) reacted immunoblots with convalescent fish sera, P. salmonis-specific antigens were only weakly detected.

Members of the Rickettsiaceae typically possess a series of antigens in the 20 to $200 \mathrm{kDa}$ range (Williams et al. 1986, Anacker et al. 1987, Lenz \& Walker 1988, Oaks et al. 1989, Hickman et al. 1993). A good example is the $120 \mathrm{kDa}$ outer membrane protein $\mathrm{B}$ (rOmpB) of Rickettsia rickettsii, which is formed from cleavage of a larger precursor (Hackstadt et al. 1992). The rOmpB protein has strong immunogenicity (Anderson et al. 1990. Ching et al. 1990) and is a candidate for a human subunit vaccine (Schuenke \& Walker 1994). Some rickettsial proteins are similar among various species. For example, the nucleotide sequence of a $17 \mathrm{kDa}$ protein found in all spotted fever and typhus group rickettsia is highly conserved (Anderson et al. 1990). While the molecular sizes of Piscirickettsia salmonis antigens are somewhat similar to those of Ehrlichia canis (Brouqui et al. 1992), molecular size alone is insufficient for comparison. Fryer et al. (1990) initially suggested that $P$. salmonis might be a member of the tribe Ehrlichieae based upon morphology and site of replication, and Lannan et al. (1991) reported that serum from a dog infected with granulocytic Ehrlichia had a fluorescent antibody titer of 1:64 against $P$. salmonis; nevertheless, analysis of the $16 \mathrm{~S}$ ribosomal RNA gene showed that $P$. salmonis was not a close relative of any rickettsia for which sequence data were compared (Fryer et al. 1992).

It is likely that other Piscirickettsia salmonis antigens await discovery. The proteins in our immunoblots were denatured by 2 -mercaptoethanol and boiling Consequently, heat-labile antigens or proteins with epitopes in complex tertiary or quaternary configurations would not be present in their native conformation. Some heatlabile antigens of Rickettsia rickettsii are strongly antigenic (Anacker et al. 1987, Lenz \& Walker 1988, Hackstadt et al. 1992) and may be important stimulators of the immune response (Schuenke \& Walker 1994). Further studies of $P$. salmonis antigens should use methods to identify a wider range of antigens, including heat-labile proteins in native configurations, glycoproteins, or antigens poorly attached to the surface of the bacterium. In addition, it will be important to use sera from hyperimmunized salmon to identify the immunodominant antigens recognized by the fish host. In fact, studies using fish antisera will be important in vaccine development because, as demonstrated by Kuzyk et al. (1996), convalescent fish antisera reacted only weakly in immunoblots with antigens that were able to stimulate a good antibody response in rabbits.

Finally, because Piscirickettsia salmonis is an obligate intracellular pathogen, stimulation of cellmediated immunity will probably be critical for success in development of effective vaccines. The role of both specific and non-specific cell-mediated immunity in protection of fish against intracellular infections is receiving increased attention. It seems likely that effective $P$. salmonis vaccines will have to be able to activate cell-mediated immunity, including enhanced phagocytosis and intracellular killing, in order to confer significant protection against disease. 
Acknowledgements. This research was partially funded by a fellowship from Alpharma Inc. We thank Cathy Lannan, Margo Whipple, and Prudy Caswell-Reno of the Hatfield Marine Science Center, Newport, Oregon, USA and Dr John Fryer of the Department of Microbiology, Oregon State University, Corvallis, Oregon, USA for providing the polyclonal rabbit antiserum and for helpful discussions. Dr Ted Hackstadt of the Rocky Mountain Laboratories in Hamilton Montana, USA provided advice regarding density gradient centrifugation, and Dr Regina Redman of the Western Fisheries Research Center, Seattle, Washington, USA provided valuable assistance in running electrophoretic gels and immunoblots.

\section{LITERATURE CITED}

Alday-Sanz V, Rodger H, Turnbull T, Adams A, Richards RH (1994) An immunohistochemical diagnostic test for rickettsial disease. J Fish Dis 17:189-191

Almendras FE, Fuentealba IC (1997) Salmonid rickettsial septicemia caused by Piscirickettsia salmonis: a review. Dis Aquat Org 29:137-144

Anacker RL, McDonald GA, List RH, Mann RE (1987) Neutralizing activity of monoclonal antibodies to heatsensitive and heat-resistant epitopes of Rickettsia rickettsii surface proteins. Infect Immun 55:825-827

Anderson BE, McDonald GA, Jones DC, Regnery RL (1990) A protective protein antigen of Rickettsia rickettsil has tandemly repeated, near-identical sequences. Infect Immun 58:2760-2769

Ausubel FM, Brent R, Kingston RE, Moore DD, Seidman JG, Smith JA, Struhl K (1994) Analysis of proteins. Current protocols in molecular biology, Chap 10. John Wiley and Sons, New York

Bradford MM (1976) A rapid and sensitive method for the quantitation of microgram quantities of protein utilizing the principle of protein-dye binding. Anal Biochem 72: 248-254

Branson EJ, Diaz-Munoz DN (1991) Description of a new disease condition occurring in farmed coho salmon, Oncorhynchus kisutch (Walbaum), in South America. J Fish Dis 14:147-156

Brocklebank JR, Evelyn TP, Speare DJ, Armstrong RD (1993) Rickettsial septicemia in farmed Atlantic and chinook salmon in British Columbia: clinical presentation and experimental transmission. Can Vet J 34:745-748

Brouqui P, Dum]er JS, Raoult D, Walker DH (1992) Antigenic characterization of Ehrlichiae: protein immunoblotting of Ehrlichia canis, Ehrlichia sennetsu, and Ehrlichia risticil. J Clin Microbiol 30:1062-1066

Ching WM, Dasch GA, Carl M, Dobson ME (1990) Structural analysis of the $120-\mathrm{kDa}$ serotype protein antigens of typhus group rickettsiae. Ann N Y Acad Sci 590:334-351

Cvitanich JD. Garate O, Smith CE (1991) The isolation of a rickettsia-like organism causing disease and mortality in Chilean salmonids and its confirmation by Koch's postulate. J Fish Dis 14:121-145

Fryer JL, Lannan CN (1994) Rickettsial and chlamydial infections of freshwater and marine fishes, bivalves, and crustaceans. Zool Stud 33:95-107

Fryer JL, Lannan CN, Garcés LH, Larenas JJ, Smith PA (1990) Isolation of a rickettsiales-like organism from diseased coho salmon (Oncorhynchus kisutch) in Chile. Fish Pathol 25:107-114

Fryer JL, Lannan CN, Giovannoni SJ, Wood ND (1992) Piscirickettsia salmonis gen. nov., sp. nov., the causative agent of an epizootic disease in salmonid fishes. Int $\mathrm{J}$ Systemat Bacteriol 42:120-126

Fryer JL, Mauel MJ (1997) The rickettsia: an emerging group ot pathogens in fish. Emerg Infect Dis 3:137-144

Garcés LH, Larenas JJ, Smith PA, Sandino S, Lannan CN, Fryer JL (1991) Infectivity of a rickettsia isolated from coho salmon Oncorhynchus kisutch. Dis Aquat Org 11:93-97

Hackstadt T, Messer R, Cieplak W, Peacock MG (1992) Evidence for proteolytic cleavage of the 120 -kilodalton outer membrane protein of Rickettsiae: identification of an avirulent mutant deficient in processing. Infect Immun 60:159-165

Hanson BA, Wisseman CL Jr, Waddell A, Silverman DJ (1981) Some characteristics of heavy and light bands of Rickettsia prowazekii on Renografin gradients. Infect Immun 34: $596-604$

Hickman CJ, Stover CK, Joseph SW, Oaks EV (1993) Murine $\mathrm{T}$-cell response to native and recombinant protein antigens of Rickettsia tsutsugamushi. Infect Immun 61. $1674-1681$

Hoiby N (1975) Cross-reactions between Pseudomonas aeruginosa and thirty-six other bacterial species. Scand J Immunol 4 (Suppl 2):187-196

Kuzyk MA, Thorton JC, Kay WW (1996) Antigenic characterization of the salmonid pathogen Piscirickettsia salmonis. Infect Immun 64:5205-5210

Laemmli UK (1970) Cleavage of structural proteins during the assembly of the head of bacteriophage T4. Nature 227:680-685

Lannan CN, Ewing SA, Fryer JL (1991) A fluorescent antibody test for detection of the rickettsia causing disease in Chilean salmonids. J Aquat Anim Health 3:229-234

Lannan CN, Fryer JL (1991) Recommended methods for inspection of fish for the salmonid rickettsia. Bull Eur Assoc Fish Pathol 11:135-136

Lannan CN, Fryer JL (1993) Piscirickettsia salmonis, a major pathogen of salmonid fish in Chile. Fish Res 17:115-121

Lannan CN, Winton JR, Fryer JL (1984) Fish cell lines: establishment and characterization of nine cell lines from salmonids. In Vitro 20:67 $1-676$

Lenz G. Walker D (1988) Protective monoclonal antibodies recognize heat-labile epitopes on surface protein of spotted fever group rickettsiae. Infect Immun 56:2587-2593

Mauel MJ, Giovannoni SJ, Fryer JL (1996) Development of polymerase chain reaction assays for detection, identification, and differentiation of Piscirickettsia salmonis. Dis Aquat Org 26:189-195

Mochida K, Lou YH. Hara A, Yamauchi K (1994) Physical biochemical properties of IgM from a teleost fish. Immunology 83:675-680

Moulder JW (1985) Comparative biology of intracellular parasitism. Microbiol Rev 49:298-337

Oaks EV, Kelly DJ, Rice R, Stover CK (1989) Antigenic and genetic relatedness of eight Rickettsia tsutsugamushi antigens. Infect Immun 57:3116-3122

Olsen AB, Melby HP, Speilberg L, Evensen O, Hastein T (1997) Piscirickettsia salmonis infection in Atlantic salmon Salmo salar in Norway-epidemiological, pathological and microbiological findings. Dis Aquat Org 31:35-48

Richter RF, Ambrosius H (1979) Anti-idiotypic antibodies of IgM-type produced in carp (Cyprinus carpio L.). Eur J Immunol 9:578-580

Richter RF, Ambrosius H (1988) The immune response of carp against dextran. Dev Comp Immunol 12:761-772

Richter RF, Emmrich F, Ambrosius H (1989) Comparative studies of the specificity of idiotypic guinea pig and carp antisera. Acta Biol Med Ger 39:295-301 
Rodger HD, Drinan EM (1993) Observation of a rickettsia-like organism in Atlantic salmon, Salmo salar L., in Ireland J Fish Dis 16:361-369

Schuenke KW, Walker DH (1994) Cloning, sequencing, and expression of the gene coding for an antigenic 120 -kilodalton protein of Rickettsia conorii. Infect Immun 62:904-909

Smith PA, Contreras JR, Garces LH, Larenas JJ, Oyanedel S Caswell-Reno P. Fryer JL (1996) Experimental challenge of coho salmon and rainbow trout with Piscirickettsia salmonis. J Aquat Anim Health 8:130-134

Stover CK, Marana DP, Carter JM, Roe BA, Mardıs E, Oaks EV (1990a) The 56-kilodalton major protein antigen of Rickettsia tsutsugamushi: molecular cloning and sequence analysis of the Sta56 gene and precise identification of a strain-specific epitope. Infect Immun 58:2076-2084

Stover CK, Marana DP, Dasch GA, Oaks EV (1990b) Molecular cloning and sequence analysis of the Sta58 major antigen gene of Rickettsia tsutsugamushi: sequence homology and antigenic comparison of Sta58 to the 60-kilodalton family of stress proteins. Infect Immun 58:1360-1368

Editorial responsibility: David Bruno,

Aberdeen, Scotland, UK
Tamura A, Urakami $H$, Tsuruhara T (1982) Purification of Rickettsia tsutsugamushi by Percoll density gradient centrifugation. Microbiol Immunol 26:321-328

Towbin H, Staehelin T, Gordon J (1979) Electrophoretic transfer of proteins from polyacrylamide gels to nitrocellulose sheets: procedure and some applications. Proc Nat Acad Sci USA 76:4350-4354

Weiss E, Coolbaugh JC, Willams JC (1975) Separation of viable Rickettsia typhi from yolk Sac and $L$ cell host components by Renografin density gradient centrifugation. Appl Microbiol 30:456-463

Wiebe ME, Burton PR, Shankel DM (1972) Isolation and characterization of two cell types of Coxiella burneti phase I. J Bacteriol 110:368-377

Williams JC, Walker DH, Peacock MG, Stewart ST (1986) Humoral immune response to Rocky Mountain spotted fever in experimentally infected guinea pigs: immunoprecipitation of lactoperoxidase ${ }^{125}$ I-labeled proteins and detection of soluble antigens of Rickettsia rickettsia. Infect Immun 52:120-127

Submitted: December 12, 1997; Accepted: April 2, 1998 Proofs received from author(s): May 8, 1998 